\title{
The Slava Celebration: A Private and a Public Matter
}

\author{
SABINA HADŽIBULIĆ \\ Åbo Akademi
}

\begin{abstract}
A family celebration named the slava or krsna slava (celebration/ glorification or christened celebration) is a unique custom within the tradition of the Serbian Orthodox Church when each family annually celebrates its patron saint. Besides Christmas and Easter, slava is the most important celebration in the life of every family. Although its roots reach as far back as medieval times, the slava and its role in family tradition were neglected and marginalised during the communist period of Serbian history. With the revitalisation of religion, and especially the reaffirmation of the Serbian Orthodox Church at the end of the last century, the slava has regained its significance and recognition, and even transcended the private family sphere. Today it is often used as an indicator of one's ethnicity and status with little real connection to its authentic religious meaning and purpose. Additionally, what was originally a family tradition has become a festival for many public institutions, companies, and professional associations. This paper aims to present the slava's distinctive structure and features, as well as to explore ways in which this transformation is related to the revitalisation of religion and the growing nationalism in transitional Serbian society.
\end{abstract}

Keywords: slava, the Serbian Orthodox Church, revitalisation of religion, nationalism.

The Serbian Orthodox Church (SOC) celebrates all Christian holidays according to the Julian calendar. ${ }^{1}$ However, what distinguishes it from all other Christian communities, even those belonging to the Orthodox tradition, is the slava or krsna slava celebration. Besides Christmas and Easter the slava is one of the most important celebrations in the life of every family. Its unique status was recognised internationally, in November 2014, when the slava celebration was included in UNESCO's Lists of Intangible Cultural Heritage, thus becoming the first Serbian intangible cultural asset to be registered. ${ }^{2}$

1 I would like to thank Professor Mikko Lagerspetz for all the insightful and knowledgeable comments regarding different drafts of this article.

2 See $<$ http://www.unesco.org/culture/ich/RL/01010>, accessed May 20, 2015. 
In what follows I will first discuss the relationship between the SOC and the Serbian state, with a focus on recent history. I will then present some of the key features of the slava family celebration by analysing its structure and some of its distinctive elements. Finally, I will attempt to describe and analyse the slava's transformation in the context of the revitalisation of religion and the growing nationalism in Serbia during the transition crisis of the last decade of the 20th century and beyond. My discussion is based on the debate in media and literature, media reports of events, and my own personal experience and involvement in the last three decades.

\section{State, Church, and nation}

The Serbian Orthodox Church (Српска православна црква) became an autocephalous church in 1219, although the modern SOC was established later, in 1920. It claims to be the second oldest Slavic Orthodox Church in the world. During the 20th century the SOC passed through several different stages in its relations with the state (Vukomanović 2001, 101-4). In the Kingdom of Serbia (1882-1918) it had the privileged position of the official state religion (1903). All state and national holidays were accompanied by church rituals, while the church's clergy had state salaries. Likewise, confessional religious education was a mandatory subject in all public schools. With the formation of the Kingdom of Serbs, Croats and Slovenes in 1918 the Serbian Patriarch became a member of the Royal Council and several priests became members of the National Assembly.

During the Second World War the SOC lost a quarter of its clergy, and many churches and monasteries were destroyed. With the establishment of the new communist government and the subsequent agrarian reform in the immediate post-war years 'the Church was deprived of its material basis, with no regular source of income, impoverished and, therefore, was dependent on state aid' (Radić 1994, 352). ${ }^{3}$ Although the church has formally separated from the state, with no open conflict between them, the dominant public discourse treated religion as an undesirable phenomenon - a 'bourgeois remnant'. The role of the SOC was marginalised and its presence reduced strictly to the private sphere. This coincided with the massive secularisation of the population of the dominantly Orthodox areas of Yugoslavia. According to the 1953 census the confessional (self-)identification of citizens was 85.2 per cent, while 12.4 per cent were atheists. Three decades later

3 It has been estimated that during the agrarian reform between 1945 and 1948 the state confiscated nearly 85 per cent of all land and properties owned by the SOC. 
almost half the population declared themselves atheist, whereas less than a quarter declared as religious (23.8 per cent), and about as many (22.8 per cent) as undefined (Djordjević 1984). The intense secularisation in homogeneously Orthodox regions had largely been conditioned by the church's de-monopolisation, as well as its continued centuries-old dependence on the state which had prevented it from creating an independent political identity (e. g. Paić 1991; Benc 1991; Radić 1995; Blagojević 1995; Vukomanović 2001). In retrospect its dependence on and constant symbiosis with the state was one of the SOC's greatest weaknesses, but it has again resulted in a new modification of its status in the public sphere.

The collapse of socialism in Central and Eastern European societies and 'the overall instability [...] of the 1990s and the late 1980s seems to have produced an experience of "value vacuum"' (Lagerspetz 2004, 9) and ideological void. After the disintegration of Yugoslavia and the period of uncertainty intensified by the civil wars in the ex-Yugoslav states (19911995), the question of religion in the public sphere resurfaced. Following decades of isolation the church again gained media visibility, and new churches and other religious buildings were constructed. Religious studies became popular again, as did both male and female monastic orders. A new wave of religious literature and journals began to be published (see, e. g., Radisavljević-Ćiparizović 2006: 37-8). The growing visibility of the church in public life was accompanied by a rapid and massive return of people to religion. Two extensive surveys on religiosity in Serbia (Blagojević 1995; Radisavljević-Ćiparizović 1999) both indicate a notable increase in religiosity at the beginning of the 90 s (with 71 per cent of respondents confessionally self-identifying), followed by a slight decrease and stabilisation at the end of the decade (with 60 per cent of respondents reporting themselves as belonging to a confession).

As Brubaker $(1996,2011)$ argues, all Yugoslav successor states demonstrated nationalising dynamics after the great reconfiguration which was a product of the 'unfinished and ongoing nature of nationalist projects and nationalization processes. [...] The reorganization of political space had produced (nominally) independent states; it had not produced 'genuine' nation-states [...]. From a nationalist point of view, the states were organizational shells that had to be filled with national content, bringing population, territory, culture and polity into the close congruence that defines a fully realized nation-state' $(2011,1786)$. In Serbia the period of 'blocked transformation' (Lazić 2005) from 1991 until 2000 was politically dominated by the goal of resolving the 'Serbian question', i. e. of creating a Serbian state 
comprising all ex-Yugoslav regions with Serbian settlements. Orthodoxy was recognised as a significant element of Serbian national identity (see, e. g., Perica 2002). The SOC became actively engaged in re-nationalisation and homogenisation by following a simple formula equating nation and religion, i. e. ethnic and confessional affiliation. This development was often publicly presented as a matter of the national culture's survival: as the church is deeply rooted in the national ethos, the latter cannot survive without the former (Ramet 1988). As the then Serbian Patriarch Pavle stated, 'To be a Serb means to be Orthodox by default....[A] Serb cannot be an atheist.... [A] Serb is never not baptized' (Srpski Patrijarh Pavle 2002).

Despite the newly created more positive relationship, the status of the SOC vis-à-vis the state remained largely undefined because of President Slobodan Milosevic's refusal to clearly determine his stance on the matter. In the public discourse religion was treated as a significant element of ethnicity, but the church still lacked any official position. It was, indeed, at the beginning of a new millennium, and with the establishment of the first democratic government in October 2000, that a striking change took place.

According to the Constitution of the Republic of Serbia (2006) the Republic of Serbia is a secular state, churches and religious communities are separate from the state, and there is no state or compulsory religion. ${ }^{4}$ Nevertheless, the transition in Serbia has been characterised by a newly established relationship between the young democratic state and the SOC, which can be said to involve the greater and more frequent participation of the church in the state and in political affairs, but can also be interpreted as the church's effort to 'provide a new ideological and value framework for the state institutions such as the school and the army' (Vukomanović 2008 , 105). This particularly refers to confessional religious education, (re-) established in all Serbian public schools in 2001, and also to the re-joining of the Orthodox Theological Faculty to the state-owned Belgrade University in 2010. Moreover, the SOC has a strong claim on property seized as part of agrarian reform and nationalisation at the end of the Second World War. Since 2001 Orthodox priests have been a part of the national army's (at that time the Federal Army of Yugoslavia) mandatory staff. At the same time one of the bishops has been made responsible for cooperation with the Army (Vukomanović 2008, 131). This new connection can be interpreted as part of a more general attempt by the SOC to restore its pre-WWII position of wealth and political privilege.

4 Constitution of the Republic of Serbia (2006), Section One, Secularity of the State, Article 11 (Ustav Republike Srbije, Prvi deo, Svetovnost države, Član 11). 


\section{The slava celebration}

The name itself denotes celebration (slava) or christened celebration ( $k r s n a$ slava), and refers to the family custom of annually celebrating a patron saint on a particular feast day. ${ }^{5}$ Other names used for this celebration are christened name (krsno ime), saint (svetac), holiday (praznik), holy (sveti), service (služba), and wisdom to the holy (pamet svetom).

Although it greatly varies, the ritual of the slava always includes a number of basic elements. According to the Encyclopaedia of Orthodoxy (Enciklopedija pravoslavlja 2002, 1056) it is based first on a prayer for the consecrated slava's boiled wheat (slavsko žito - koljivo). The wheat represents a bloodless sacrifice prepared for both the celebration of god and the celebration of a saint, as well as for the souls of deceased family members and the health and prosperity of the living. Necessary elements of the ritual are also the slava cake/bread (as a sacrifice and praise to God), the slava candle (as a sacrifice from the pure and fragrant soul of the celebrating family), sacred water, red wine (to be poured over the cake), incense (tamjan) (as the pleasure of celebration), and oil (as a sacrifice to God). Ham as a blood sacrifice is part of the ritual only if the slava is not celebrated during the fasting season.

The celebration of the slava should start at church, when the slava cake and wheat for consecration (Sinani 2012, 176) are offered. An Orthodox priest, together with the family, takes part in the consecration ceremony in which the slava cake is cut in the shape of the cross as a symbol of Christ's suffering, and red wine is poured over it, signifying that the family is now released of all its sins. This traditional part of the custom is completed by the cutting of the slava cake into four parts as it is lifted up. It can be conducted in the church or at the family home 'by the host together with the oldest or the most important guest (dolibaša), the host's heir, and other family members' (UNESCO Representative List 2014, 3). The celebration then continues at the family home, where the slava feast starts with a toast by the host in honour of God and the patron saint. According to tradition a multitude of dishes on the table of the feast secures the progress and fruitfulness of the coming year. The dishes are eaten with friends and acquaintances - collectively, according to a determined schedule, using imitative magic to capture happiness and prosperity (Vlahović 1968, 127).

The custom seeks to make a Serbian Orthodox family part of the church by filling it with the church's and God's blessing (Radisavljević-Ćiparizović

5 According to the Christian liturgical year every day of the year is dedicated to one or more saints and is called a feast day. 
2006, 78). In church tradition the slava is generally understood as a holy day of the 'small church', since a Christian family is regarded as a household, or small church. ${ }^{6}$ As a joint celebration of the family as a collective the slava is the only holiday that 'belongs to a certain, specific family' (Bandić 1986, 18). In this respect the former Serbian Patriarch Pavle emphasised:

Other Christian Orthodox people celebrate their name days or birthdays, but we, on the other hand, celebrate our patron saint's day. Actually, the patron saint's day is both a name day and birthday, not of an individual, but of the entire family, the whole tribe. It is a spiritual birthday, when our ancestors became Christians, entered the Church of God and were thus spiritually born. And it is also a name day, because as of that time up until now they have been called Christians (Srpski Patrijarh Pavle 2009).

According to Serbian Orthodox tradition there are seventy-eight patron saints or Christian names celebrated as slava (Vojnović 1963). The most popular is St Nicholas (St Nicholas's Day - Nikoljdan) on 19th December, which, it is estimated, about half the Serbian Orthodox population celebrates. A traditional Serbian saying states that everyone celebrates on St Nicholas's Day, because half the population is celebrating, while the other half is invited to visit and participate in the celebration. ${ }^{7}$

The earliest reference to the slava is in 1018, when the Greek chronicler Skilica described an occurrence at the home of Duke Ivac, whose enemy misused the slava custom of receiving even uninvited guests in order to come and hurt him (Prokić, cited by Vlahović 1968, 120). Although Skilica makes no direct reference to the slava, the feast he describes is similar. The slava was later thoroughly described by a Serbian philologist and linguist who was the major reformer of the Serbian language, Vuk Karadzic (Vlahović 1968, 120 ), in one of his celebrated works at the beginning of the 19th century. ${ }^{8}$

Because the slava is specific to and widespread among Serbs there are numerous interpretations of its origins and development. Despite a lack of sources the most frequent reconstructions of the roots of the slava are

\footnotetext{
6 In support of this argument the SOC usually refers to Paul's words, 'Greet Priscilla and Aquila [...] and the church that meets in their house' (Rom.16:3-5), as well as his greeting to 'Philemon, our beloved friend and fellow worker [...] and to the church in your house' (Philemon 2).

7 Also among the most common are St George, with two celebrations in the year (Djurdjevdan on 8th May and Djurdjic on 16th November), and St Archangel Michael (Arandjelovdan) on 21st November.

8 The work in question is the first Serbian dictionary (Srpski riječnik) of 1818, written in the newly reformed language.
} 
based on two key arguments, both of which rely for the most part on interpretations of the ceremonial props used in the celebration. Several authors refer to pre-Christian times, interpreting the tradition as a compromise between Christianity and the old religion, which included a transfer of the cult of pagan gods and heroes to the characters of saints (e. g. Vasić 1901/1985; Skarić 1912; Čajkanović 1921, 1940; Truhelka 1985). In the light of these arguments the slava was regarded as a type of cult of collectivity, while 'its several days' ritual, to a great extent, reflects a specific assimilation or syncretism between the old pagan and Christian motifs, acts, and symbols' (Vukomanović 2001, 71). However, another group of academics emphasises the church's role in the creation and development of this custom. They stress the importance of reforms introduced by the first Archbishop of the SOC, Sava the First (Rastko Nemanjić, later also known as St Sava) in the 12th century (e. g. Grujić 1985; Bogdanović 1985; Kalezić 2000). The claims of the historian Dimitrije Bogdanovic (Bogdanović 1985) reflect such arguments:

The creator of the slava is exactly the church of St Sava. The slava is the cult of St Sava. Thus, only Serbs, as the ethnic group that has been exposed to the continuous and determining influence of the church of St Sava, are the ones who celebrate the slava today. The slava thus represents one type of missionary practice of the church of St Sava, one form of its fight against paganism, for a more complete evangelisation of medieval Serbia (Bogdanović 1985, 510f.).

Notably, the SOC's own interpretation follows the same view, i. e. it opposes the argument that the origin of the slava lies in the Christianisation of pagan cults. The following statement of one of the representatives of the SOC stands as a typical example of such a view:

We reject this interpretation as incorrect and unfounded [...]. And it (the slava) is related to the most significant day in the life of our ancestors. On that day, through christening, they became members of the Church of Christ and were spiritually born. As a matter of fact, that day of christening is their spiritual birthday. In honour of their christening they started celebrating the slava of christening, or the feast day or the saint of that day. Mother Church blessed it and proclaimed the krsna slava as a Christian institution (archpriest Života Mihajlović 2000). 
The slava can be inherited and chosen according to many different criteria, the most common being transference from a father to a son (Sinani 2012, 175). The oldest son in a family inherits it from his father and passes it, in turn, to his oldest son. If the slava is passed during the lifetime of the host, this is usually accompanied by a symbolic act in which the father gives the son a piece of cake. A woman can be a slava host if she becomes a widow, and hence inherits her late husband's family celebration. There are rare cases when a slava is inherited through the purchase of land or houses, and thus received through property. These cases, however, are largely confined to rural areas and the past. Besides, 'a slava can be brought to a new family by marriage, or it can be accepted through a vow or likewise - there are many ways to take over or chose a slava' (Sinani 2012, 175).

If a family has inherited no slava but is willing to celebrate one, the protopresbyter Stavrofor Slobodan Lalic (Lalić 2016) explains:

A newly christened male person can get a slava in agreement with the priest who christened him. There is no rule which should be strictly followed in this case [...]. Of course, it is welcomed that the person himself suggests a saint to be celebrated. Usually, that choice is determined by the characteristics of the saint's life and his or her interpretation of Christianity (Lalić 2016).

Usually, a family celebrates one patron saint, and some can trace their slava tradition through several generations. Once chosen, a slava should not be changed. Such a change happens only because of major family or personal distress. Even in such cases the old slava is never forgotten or neglected, but remains as a more moderately celebrated side-celebration called the pre-slava (preslava) or little slava (mala slava).

\section{Slavas today}

The increased visibility of the SOC in the public sphere, as well as its politicisation and political instrumentalisation, has had a profound effect on even private and personal religious acts of devotion such as family celebrations. Data on celebration of religious holidays provided by the research of Djordjević (1984), Blagojević (1995), and Radisavljević-Ćiparizović (1999) show that the indicator of traditional connectivity to church and religion 
closely follows the dynamics of general religiosity in Serbian society. ${ }^{9}$ Hence, the number of people celebrating religious holidays in 1984 was 56.7 per cent, while in 1993 it increased to almost 94 per cent. At the end of the century a stable 87 per cent of the population was registered as being religious. However, the percentage of people celebrating religious holidays is always higher than the percentage of those who report themselves as religious, implying that many of those who declare as atheists or nonbelievers do in fact actively participate in religious celebrations. These celebrations are therefore always about something more than just religion.

\section{The family slava}

As shown above, the slava is the day when a family is symbolically placed under the protection of a saint to whom it turns to as its prayer representative before God, and to whom it annually pays its respect. From that moment, according to Serbian Orthodox tradition, the church has entered the family home and brought a new spiritual meaning to it. Hence, the religious function of the slava seems both unique and transparent. The slava is not just one of the family holidays, but the only holiday devoted to a particular family (Bandić 1997, 246). As such it represents a private experience of the highest rank that celebrates not only a patron saint, but the unity of the family, as well as its will and strength to persist in time and faith. By celebrating their slava a family is announcing its identity in a distinctive way. It is a uniquely and specially understood feature. This 'denoting potential of the slava' (Bandić 1997) has been used for different purposes by many.

The latest flowering of religion has led to a new recognition of the place of the slava, shown in a rapid increase in the number of families celebrating it. For some the slava was a family experience deliberately forgotten for almost fifty years that now needed to be revived. For others the slava was the first step into a newly discovered territory of spiritual identity. For both its importance lies in the opportunity to show one's religious affiliation and ethnic identity. The slava represents one of the most important elements in the national symbolism of Serbs, so it almost goes without saying that the family which celebrates it is Serbian (Sinani 2012, 190).

The slava is not celebrated alone, but with the front door open to all family friends, as it is also an opportunity for people to meet and socialise.

9 According to these researches the indicator of traditional connectivity to the church and religion refers to practice and participation in traditional religious rituals such as the christening of a child, church funerals, and the celebration of religious holidays. 
Guests contribute to the collective spirit, and to the family as a unique collective. Many host families consider the slava a central annual event, and try to make it more visible by including more guests in it. The increased number of invitees is one of the reasons the celebration has increasingly moved out of host families' homes and become a public event celebrated in restaurants or wedding or lunch halls. Sometimes the celebration lasts for three or more days. This extended celebration sends a clear message about the host family's commitment to this unique Serbian Orthodox custom, and thereby to its own identity. At the same time it makes a strong statement about the family's social status and power, since organising such sometimes quite impressive gatherings requires some resources. Although it is legally possible to receive a day's paid leave for the celebration, many are forced to take some extra days because of all the challenges its organisation entails. The most demanding part is the feast. It usually includes four to five courses, each of several dishes. Large quantities of alcohol and soft drinks are made available. According to some media estimates the average cost of a slava table in 2013 was almost twice the average Serbian monthly income (Dragović 2.11.2013).$^{10}$ As one slava host stated in the media: 'No matter how much the guests consume, the host needs to have everything necessary ready' (Petrović 8.12.2013). Guests are also involved in this competition, as they are expected to bring presents for the host. Furthermore, people are sometimes invited to several different celebrations on the same day. A traditional belief suggests that one should not refuse an invitation to a slava as attending its celebration is an act of respect for the host family. Regardless of this, one slava host is reported as saying: 'We must always have (the means) for a slava, and we will find the ways to cover the minus afterwards' (Avalić 17.12.2014).

Media outlets are keen to show Serbian public figures celebrating their slava with many celebrity guests, a rich feast, and protracted festivities. ${ }^{11}$ Such reports and pictures suggest that the sublime and transcendent purpose of this private family event has been completely neglected and even forgotten. Besides, some basic elements of slava ritual are often banalised or avoided. Some families do not prepare the slava wheat at all, nor do they make the slava bread in the family but pre-order it. Nor do they observe the consecration of the ritual elements of the slava, or observe fasting and non-

10 In some cases entertaining a large number of guests brings the extra expense of providing live music and catering staff.

11 See e. g.: <http://www.svet.rs/nas-svet/estrada/domacinski-brena-i-boba-proslavili-krsnuslavu-svetog-arandela> accessed May 30, 2015. 
fasting days in accordance with the traditional calendar. Some are so busy with all the organising that they do not find time to attend the liturgy on the slava day. Although 'the slava is not about eating and drinking, but about bread, wheat and candle' (Bilinac 2012), many know little of the saint they celebrate. Inevitably, a market for slava props has emerged, so slava candles are now available in different sizes and colours, and there are competitions for the most beautiful slava bread. ${ }^{12}$

\section{The slava as a school celebration}

The slava celebration opened the way into the public sphere for the SOC by making it possible for its representatives to gain official access to the educational system through public schools. Shortly after the old system collapsed at the beginning of the nineties, the slava celebration dedicated to the first Serbian Archbishop and prominent medieval intellectual St Sava was established in all public schools as a mandatory school holiday. This revived a practice that was customary from 1840, when it was legally declared a general school celebration, until 1945, when the authorities abolished it.

According to church tradition St Sava was proclaimed the protector of all schools. The slava of St Sava, or St Sava's Day (Savindan), has been celebrated on the day of his death, 27th January, every year in all public schools. There are no classes on this day, but the attendance of all students and teachers at the celebration is compulsory. Its central part is a ceremony based on the ritual of breaking the slava cake and toasting. It is followed by a mixed programme of music and drama jointly created by teachers and students, along with a feast for all the participants and guests. The celebration often includes a larger public celebration in the evening called the St Sava Academy (Svetosavska akademija), attended by state and church officials. Its programme includes a variety of speeches, poetry, and music related to the life and work of St Sava. ${ }^{13}$

The religious message is explicit in the numerous pictures, videos, and descriptions of the event available online. ${ }^{14}$ Slava related props, icons, and priests are prominently visible at the celebration. At many schools students

12 See e. g.: <http://www.smederevo.org.rs/Print-Smederevo_408_cir> accessed 9th June 2015. Or: <http://www.smederevo.org.rs/OpstinaSmederevo-Na-Dan-Sv.-Atanasija-izlozen141-slavski-kolac_626_cir>, accessed 9th June 2015.

13 The Belgrade St Sava Academy is broadcast live on the Serbian state-owned television channel.

14 Some of the websites used as examples in this analysis are listed in the references section at the end of the paper. 
and teachers attend the liturgy. ${ }^{15} \mathrm{~A}$ similar celebration is organised in some pre-schools and kindergartens with the aim of this becoming a regular annual event.

Despite the positive public discourse about the school slava as a significant Serbian educational tradition, its practice has faced criticism, mostly from scholars and intellectuals. A study of primary school students in the Serbian capital (Malešević 2007) reported on the importance of this day in the life of each school as a transparent indicator of modern schools' identity, and hence of the basic and most important values of Serbian society. This is aptly shown by a description of the interior of a typical primary school in the capital ${ }^{16}$ :

In the main hall, on all the boards, display cases, and walls, there are pictures with only religious contents. Students' creative achievements are represented by two exhibitions of their most beautiful works: the first theme is the decorating of Easter eggs, and the second is the portrait of St Sava. In one display case the children's literary works for a competition dedicated to St Sava, 'the Serbian teacher and educator', are displayed. In the next display case there are ten photographs from the last school slava, capturing the most significant moments: the school director and the priest breaking the slava cake, parents and teachers standing with candles in their hands while the priest reads the prayer, children in national costumes performing appropriate programmes (...). On the first floor, on the main wall across from the teachers' room, there is a big painting of St Sava surrounded by children, called St Sava Gives his Blessing to Little Serbs (Malešević 2007, 136f.).

School identity built on the slava as a central event has an explicitly religious dimension, although other interpretations of the celebration would be possible given that $\mathrm{St}$ Sava is a significant historical figure because of his educational, teaching, and diplomatic role. The religious dimension's dominance has raised objections from the mainly Muslim Bosniaks of Western Serbia, among others. They have interpreted the celebration of the school slava as 'an act of violation of religious and human rights [...]. The state should not,

15 In some schools in Belgrade special honour was given to Prince Aleksandar II Karadjordjevic, the heir of the pre-war Serbian dynasty, who returned to Serbia after decades of exile after the fall of communism.

16 As part of this study the author visited several primary schools, and was greatly surprised by what she found. The cases were more or less similar, and I present here the one her paper singles out. 
by any regulations and laws, declare that day as a school slava, especially not [as obligatory] for all teaching staff and students [...]' (Isabegović 2011). This brings into question the (in)ability of schoolchildren to identify with the day, and, accordingly, properly interpret the entire event. It also results in the imposed separation of schoolchildren based on confessional and national belonging. In a broader context the school slava also raises concerns about 'a quiet attempt to assimilate and christen Bosniaks' (Isabegović 2011).

The SOC's presence in the public sphere has now expanded to other public institutions which have adopted the tradition of celebrating a patron saint as their protector. Public slava celebrations of state-owned institutions, private companies, towns, and even political parties have become common.

\section{Institutional slavas}

According to Serbian Orthodox tradition it is a common practice that a church, monastery, or temple is under the patronage of one saint or more, so each has its own slava. Almost every town has one or several sites for religious ceremonies. The socialist era brought about new social circumstances and changed existing practice. However, since the 1990s it has become increasingly common to present the patron saint of the local church as the patron of the town itself. Thus, the day of the church slava becomes the day of the town slava, i. e. the day of that town, an important annual event. ${ }^{17}$ This pre-war practice has been revived in almost every Serbian municipality. ${ }^{18}$

The celebration of town and municipal slavas usually starts with the liturgy in the central town church, which is followed by the official procession (litija) through the streets of the town centre. The ritual of the breaking of the bread is observed in the town hall, on the central town square, or in the grounds of the church. It is common to conclude the celebration with a feast in the town hall or in the grounds of the church. The larger and richer municipalities celebrate their slava for three to ten days, and the celebration is accompanied by various cultural and sports events paying homage to Serbian national traditions. The organisers, i. e. the hosts, of a town slava are both the town officials and the representatives of the SOC. They are supported by the representatives of the Serbian Army, police, and leaders of major cultural institutions. In many cases the town slava also has a godfather,

17 A list of websites with examples of town slavas is given in the references at the end of this paper.

18 In towns consisting of several municipalities there are several individual slavas for each, besides the central town slava. 
who is usually the head of one of the most important public institutions. ${ }^{19}$

One of the striking examples of this practice is the Belgrade slava. According to the city's official website the Ascension of the Lord (Spasovdan) became its slava as early as 1403, when Belgrade was declared the nation's capital. ${ }^{20}$ The celebration was revived in 1992 in a procession led by the then Serbian Patriarch Pavle, so the media often refer to this town slava as 'the legacy of Patriarch Pavle' (Blic 21.5.2015). The culmination of the celebration is a procession through the centre of the city, which symbolically completes a circle in the grounds of the Church of the Ascension, built as the town church in 1863. The procession is led by the Serbian Patriarch, numerous SOC and local government officials, Prince Aleksandar Karadjordjevic, and the representatives of the Serbian Army and police, followed by the citizens, and lasts for several hours. At the suggestion of the current Patriarch Irinej the entire procession is preceded by the cavalry and students of the Military Academy. Representatives of the police and army carry large icons, while male Orthodox seminarians, dressed in church robes, carry smaller icons and the banner and the flag of the City of Belgrade. The cross of Jerusalem has a prominent place at the front of the procession. Groups of young people also join the procession dressed in Serbian national costume. The procession stops at several locations for a prayer (moleban) to be read. The Mayor of Belgrade lights the ceremonial candle and carries the icon of the Ascension of the Lord into the building of the Municipal Assembly, where the ceremony of the breaking of the bread follows. The entire procession is broadcast and comprehensively reported by several media channels.

The town spokesman describes the slava celebration as a significant tradition and as a day for all the citizens. However, apart from the sporadic cultural events of the accompanying programme, the celebration's explicitly religious dimension conveys a uniform message that leaves little room for any other interpretation. ${ }^{21}$ The overall conception and details of the celebration are also a declaration of continuity with the pre-war period. On the occasion of one of Southern Serbia's largest town's slava, its mayor stated 'that in the previous period, the celebration of the town slava was occasion-

19 For example, the godfather of the town slava of the second largest city in Serbia, Novi Sad, is the president of the oldest Serbian literary, cultural, and scientific society, Matica srpska, which is based in the city.

$20<$ http://www.beograd.rs/cms/view.php?id=1218>, accessed 25th May 2015.

21 The town slavas are also used as an opportunity for certain state institutions to begin working or to be re-opened after renovations and consecrated and blessed by local clergy. In writing this paper I have found examples of the opening and blessing of healthcare institutions, local municipal government offices, theatres, roads to a church located outside the town, etc. 
ally interrupted, and the connection between the people and the church is especially expressed today' (Južna Srbija info 9.6.2014). His brief statement encapsulates the idea and goal of the entire event.

Media outlets offer regular reports of the slava celebrations of government institutions, political parties, healthcare centres, professional associations, etc. $^{22}$ In January 2015 the public municipal water supply company Vodovod in Novi Sad, the administrative centre of a multi-ethnic province with six official languages, celebrated its slava by consecrating the city's drinking water. The act of consecration aimed to 'symbolically transfer the blessing to the water distributed to all the citizens of Novi Sad via the water supply system' (B92 20.1.2015). This provoked a strong response from numerous citizens of other confessions, as well as from non-governmental organisations. The provincial Ombudsman condemned what had happened, stating that it was a violation of the constitution, as Serbia was a secular country in which church and state were separate.

The role of Vodovod is to supply all the citizens, regardless of their nationality, language, religion, or any other personal characteristic, with highquality drinking water. It is inappropriate for the public institutions, as executors of public authority, to celebrate religious holidays and hence question basic constitutional principles. The role of the state is to enable everyone to follow and practise a religion of their own choice, rather than through a public institution exclude particular religions and traditions and thus call into question the constitutionally guaranteed equality of the citizens (B92 20.1.2015).

Similar criticism was expressed by several academics and intellectuals. The act was widely interpreted as a transparent imposition of religion on those who were neither believers nor members of the SOC, which 'in any case ... could not be justified by the canons of the SOC at all [...]. It all looks like show business and the commercialisation of religious customs' (Nikola Knežević, cited in B92 20.1.2015). It was also emphasised that:

These customs introduce additional divides into our heterogeneous society [...]. There are 30 religious communities in Novi Sad [...], and around 180 in

22 For example, special coverage is given to the slava of the Serbian police and the Ministry of Internal Affairs which, along with the breaking of the slava bread in the Minister's office, also includes a parade of police officials and combat vehicles of the members of the Ministry of Internal Affairs, and tactical exercises of the police. 
Serbia. Does this mean that each of these can now enter public institutions [...] and practise its own rituals? Or do we simply talk about one church being favoured over the others and hence acting from a position of power? (Miroslav Keveždi, cited in B92 20.1.2015)

Recently, many state universities have joined the list of public institutions celebrating a slava. The celebrations follow the same course, with the inevitable ritual of the breaking of the bread and a speech in honour of the saint. At the first celebration of the slava of the Faculty of Medicine at one of the biggest universities in Serbia, attended by the mayor, the dean, professors, students, and numerous guests, a church official said:

From the beginning of time both science and medicine (...) have discovered and provided medications, but the medicine for immortality has not been given by anyone but Christ (...). That winner and excellent doctor was chosen by St Sava, (...) who was the founder of medicine in our country, since our monasteries were the first healing places and hospitals. By celebrating St Sava we are going in the direction of receiving the eternal medicine, the medicine of immortality and the kingdom of heaven (Bishop Jovan of Nis, interview, 2014).

This statement expresses the SOC's tendency to present its connection with the Serbian state and nation as organic and inseparable. Simply to choose Christ's path (and, implicitly, Orthodoxy) brings 'medicine and healing'. The reference to St Sava also serves as a way of emphasising the specificity of Serbian Orthodoxy and its significance for Serbian society. The SOC and its founder are here defined as founders of some of the society's most prominent institutions.

\section{Conclusions}

The slava is a complex celebration. Besides having a distinctively religious character, its social aspect is mostly expressed through the feast as a profane element, and its function in regulating interpersonal and intergroup social relations is based on the reciprocity of hospitality (Bandić 1997; Sinani 2012). It also promotes the integrity of the family, as well as its integration within the wider community. Simultaneously, the slava has increasingly been understood as a sort of national ethnic Serbian symbol. From a wider perspective, however, this transformation raises a number of questions. 
The post-socialist transition brought about, among other things, a closer relationship between the post-socialist state and the SOC. In terms of the greater awareness of religion and its renewed presence in the public sphere one can argue that Serbian society may be regarded as post-secular, as defined by Habermas (2008). However, the case of the slava celebration and its new public role testifies to the favouritism shown by the state to the SOC. Instead of exercising a neutral and secular role that enables tolerance between different views and religious communities (Habermas 2007), the government seems to be developing a symbiotic relationship with the church, as is shown by the latter's privileged position in the public sphere. This is evident in the school slava, which neglects other possible interpretations of St Sava's role in Serbia's educational history. The opportunity to give it a wider meaning acceptable to all students, irrespective of their religious affiliation or lack of it, has been lost. The same can be said about the slavas of other public institutions, especially the town slavas. The display of strongly religious and national symbols and the important part played by selected guests and invitees do not indicate a tolerance for and openness to everyone. The town signals its devotion to tradition, but at the same time its neglect of those outside it - such as citizens of other confessional affiliations, atheists, immigrants, and non-Serbs.

In the post-socialist transition the desire to 'return' to older national and political traditions became the starting point of a much-exploited political discourse (Lagerspetz 1999). The new flourishing of the slava custom, an important part of Serbian Orthodox tradition, also reflects this desire. However, a tradition, with everything it stands for, can never be recreated as being identical with something in the past. It is not a 'frozen image', but will rather follow the needs of the current social context, and be reinterpreted accordingly. In today's Serbia the desire to 'return' easily leads to a failure to recognise society's real cultural and religious diversity. The past provides no self-evident argument for a restoration tout court of the pre-WW II status, privileges, and social impact of the Orthodox Church. The revival and new visibility of the slava tradition has emphasised its religious and ethnic dimensions. It has become a channel to advocate nationalist ideas and conservative political attitudes, allowing no room for alternative identities, loyalties, and ways of belonging. From today's perspective, however, the tradition also has a larger potential to promote the ideal of egalitarian relationships, which could be seen as one of its key features. In another setting, promoting inclusiveness and community spirit as its key values, the slava could be regarded as an annual gathering of all Serbian citizens. 
As a long and important tradition the slava will certainly remain an element of Serbian public and private lives for a long time to come. Significantly, it is a tradition with a rare capacity to relate to several spheres of life - the private, the public, the ecclesiastical, and the mundane. For the time being much of its obvious potential to create bonds between members of society has however been sacrificed to the church's quest for influence and the state's quest for legitimacy. Opening the slava to new, alternative, cooperatively motivated interpretations might give everyone a chance to identify with a shared celebration.

SABINA HADŽIBULIĆ is Post-Doctoral Researcher in Sociology, Åbo Akademi, Finland. E-mail: sabina.hadzibulic@abo.fi

Bibliography

Interviews

Lalić, Slobodan

2016 E-mail interview, 4.9.2016, in the possession of the author.

Books and articles

Bandić, Dušan

1986 Funkcionalni pristup proučavanju porodične slave. Glasnik Etnografskog instituta SANU 35, 9-19.

1997 Carstvo zemaljsko i carstvo nebesko. Beograd: XX vek.

\section{Benc, Ernst}

1991 Veličina i slabost pravoslavlja. - Dragoljub Djordjević (ed.), Pravoslavlje izmedju neba i zemlje, 25-30. Niš: Gradina.

\section{Blagojević, Mirko}

1995 Približavanje pravoslavlju. Niš: Gradina \& Junir.

2005 Religija i crkva u transformacijama društva. Beograd, IFDT \& IP "Filip Višnjić".

\section{Bogdanović, Dimitrije}

1985 Krsna slava kao svetosavski kult. Ivan Kovačević (ed.), O krsnom imenu, 486-511. Beograd: Prosveta. 


\section{Brubaker, Rogers}

1996 Nationalism Reframed: Nationhood and the National Question in the New Europe. Cambridge: Cambridge University Press.

2011 Nationalizing States Revisited: Projects and Processes of Nationalization in Post-Soviet States. Ethnic and Racial Studies 34 (11), 1785-1814.

\section{Djordjević, Dragoljub B.}

1984 Beg od crkve. Knjaževac: Nota.

\section{Enciklopedija pravoslavlja}

2002 Enciklopedija pravoslavlja 3. Beograd: Savremena administracija.

\section{Grujić, Radoslav}

1985 Crkveni elementi krsne slave. Ivan Kovačević (ed.), O krsnom imenu, 407-85. Beograd: Prosveta.

\section{Habermas, Jürgen}

2007 Mellan naturalism och religion. Filosofiska uppsatser. Göteborg: Daidalos.

2008 Notes on a Post-Secular Society. New Perspectives Quarterly Fall, 17-29.

\section{Lagerspetz, Mikko}

1999 Postsocialism as a Return: Notes on a Discursive Strategy. East European Politics and Societies 13 (2), 377-90.

2004 The Hegemony of the Convertible. Mihhail Lotman (ed.), Kultuuri maailmad. Acta Collegii Humaniorum Estoniensis, 9-18. Tallinn: Eesti Humanitaarinstituut.

\section{Lazić, Mladen}

2005 Promene i otpori. Beograd: Filip Višnjić.

\section{Kalezić, Dimitrije M.}

2000 Krsne slave u Srba. Beograd: Narodna knjiga.

Kolarov, D.

1960 Krsna slava. Vršac: Srpska pravoslavna crkva.

\section{Malešević, Miroslava}

2007 Žensko - Etnografski aspekti društvenog položaja žene u Srbiji. Beograd: Srpski genealoški centar.

\section{Paić, Gordana}

1991 Srpska pravoslavna crkva i kriza. - Dragoljub Djordjević (ed.), Pravoslavlje izmedju neba i zemlje, 10-12. Niš: Gradina.

\section{Perica, Vjekoslav}

2002 Balkan Idols: Religion and Nationalism in Yugoslav States. Oxford: Oxford University Press. 


\section{Ramet, Pedro}

1988 Autocephaly and National Identity in Church-State Relations in Eastern Christianity: An Introduction. Pedro Ramet (ed.), Eastern Christianity and Politics in the Twentieth Century, 3-19. Durham, NC and London: Duke University Press.

\section{Sinani, Danijel}

2012 O proučavanjima porodične slave u Srbiji. Etnološko-antropološke sveske 19 (8), 175-92.

\section{Skarić, Vladislav}

1912 Postanak krsnog imena. Glasnik zemaljskog muzeja 32, 245-77.

Truhelka, Ćiro

1985 Larizam i krsna slava. Ivan Kovačević (ed.), O krsnom imenu, 342-406. Beograd: Prosveta.

\section{UNESCO Representative List}

Nomination file no. 01010 for Inscription of the Representative List of the Intangible Cultural Heritage of Humanity in 2014. Intergovernmental Committee for the Safeguarding of the Intangible Cultural Heritage. Ninth session. Paris, France, November 2014. Available at: www. unesco.org/culture/ich/RL/01010, accessed on 9 May 2015.

\section{Vasić, Miloje}

1985 Slava - krsno ime. Ivan Kovačević (ed.), O krsnom imenu, 407-25. Beograd: Prosveta.

\section{Vlahović, Petar}

1968 Prilog proučavanju krsne slave. Slavenski etnograf 20, 120-28.

\section{Vojnović, $\mathbf{H}$.}

1963 Srpska slava ili krsno ime. Beograd: Sveti arhijerijski sinod SPC.

\section{Vukomanović, Milan}

2001 Sveto i mnoštvo. Beograd: Čigoja štampa.

2008 Homo viator: religija i novo doba. Beograd: Čigoja štampa.

\section{Radić, Radmila}

1994 Uticaji razvoja Srpske pravoslavne crkve na modernizacijske procese u Srbiji i Jugoslaviji. Srbija u modernizacijskim procesima 20. veka 1, 349-55.

1995 Verom protiv vere. Beograd: INIS.

\section{Radisavljević-Ćiparizović, Dragana}

2006 Religioznost i tradicija: Vezanost ljudi za religiju i crkvu u Srbiji na raskršću milenijuma. Beograd: Čigoja štampa. 


\section{Čajkanović, Veselin}

1921 Nekolike primedbe uz Badnji dan i Božić. Godišnjica Nikole Čupića 34, 258-88.

\section{Čajkanović, Veselin}

1940 Krsna slava. Srpski glas 7, 123-32.

\section{Websites}

\section{Avalić, Gorica}

2014 Istražili smo: Evo koliko košta slava u Srbiji. - Arhiva 24 sata <http:// arhiva.24sata.rs/specijal/zivot/vest/istrazili-smo-evo-koliko-kostaslava-u-srbiji/160947.phtml>, accessed May 192015.

B92

2015 Ombudsman osudio osveštanje vode. - B92 <http://www.b92. net/info/vesti/index.php? yyy $=2015 \& \mathrm{~mm}=01 \& \mathrm{dd}=20 \&$ nav_ category=12\&nav_id=948892>, accessed April 12017.

Blic

2015 Zavet Patrijarha Pavla: Evo zbog čega Beograd slavi Spasovdan. - Blic $<$ http://www.blic.rs/Vesti/Beograd/560858/ZAVET-PATRIJARHAPAVLA-Evo-zbog-cega-Beograd-slavi-Spasovdan>, accessed May 21 2015.

Blog Osnovne škole Heroj Radmila Šišković

2015 Obeležavanje školske slave Sveti Sava u OŠ Heroj Radmila Šišković. - Blog Osnovne škole Heroj Radmila Šišković <http://blog.oshrs.edu. rs/2015/01/2015-01-2627.html>, accessed May 232015.

Blog Osnovne škole NH Dušan Dugalić

2015 Školska slava Sveti Sava. - Blog Osnovne škole NH Dušan Dugalić <http://osdusandugalic.blogspot.fi/2015/01/skolska-slava-sveti-savau-os-dusan.html>, accessed May 252015.

\section{Dragović, Rade}

2013 Nema slave bez 300 evra. - Večernje novosti online <http://www.novosti. rs/vesti/naslovna/ekonomija/aktuelno.239.html:461898-Nema-slavebez-300-evra>, accessed May 19, 2015.

\section{Erić, Nevenko}

2012 Krsna slava, dan praznovanja svetitelja. - Pravoslavni bogoslovski fakultet<http://www.ues.rs.ba/lat/bogoslovski-fakultet/vijesti/krsnaslava-dan-praznovanja-svetitelja>, accessed May 25, 2015.

\section{Isabegović, Haris}

2011 Sveti Sava nije naša slava. - Sandžak Press elektronske novine <http:// sandzakpress.net/sveti-sava-nije-nasa-slava>, accessed April 3, 2017. 


\section{Južna Srbija info}

2014 Leskovac: Obeležena gradska slava. - Južna Srbija info <http://www. juznasrbija.info/vesti/leskovac-obelezena-gradska-slava.html>, accessed May 26, 2015.

\section{Mihajlović, Života Protojerej}

2000 Srpske slave i običaji. - Sv. Stefan - Serbian Orthodox Church, Ottawa, Canada $<$ http://www.svetistefan.ca/veronauka/krsnaslava.html>, accessed May 10, 2015.

\section{Niška televizija NTV}

2014 Krsna slava Medicinskog fakulteta (VIDEO). - Niška televizija NTV $<$ http://ntv.rs/krsna-slava-medicinskog-fakulteta/>, accessed May 20, 2015.

\section{Novi Magazin}

2013 Spasovdanska litija u Beogradu (Foto). - Novi magazin <http://www. novimagazin.rs/vesti/spasovdanska-litija-u-beogradu-foto $>$, accessed May 182015.

\section{Opština Titel}

2015 Obeležena školska slava Sveti Sava u srednjoj školi u Titelu. - Opština Titel <http://www.opstinatitel.rs/clanak.php?r=br-1498/Обележенашколска-слава-Свети-Сава-у-средњој-школи-у-Тителу.html>, accessed May 26, 2015.

\section{Osnovna škola Branko Radičević Bujanovac}

2015 Svečano obeležena školska slava Sveti Sava. - Osnovna škola Branko Radičević <http://osbrankoradicevicbujanovac.nasaskola.rs/vesti/47/ SVECANO-OBELEZENA-SKOLSKA-SLAVA-SVETI-SAVA/>, accessed May 25, 2015.

\section{Osnovna škola Kosta Tripković}

2013 Sveti Sava školska slava. - Osnovna škola Kosta Tripković<http://www. kostatrifkovicns.edu.rs/stari/SvetiSava.html>, accessed May 25, 2015.

\section{Petrović, V.}

2013 Za Svetog Nikolu najmanje 500 evra. - Belle Amie portal < http://www. belami.rs/za-svetog-nikolu-najmanje-500-evra/>, accessed May 19, 2015.

\section{Predškolska ustanova Savski venac}

2015 Školska slava Sveti Sava. - Predškolska ustanova Savski venac <http:// www.pusavskivenac.edu.rs/skolska-slava-sveti-sava/>, accessed May 25, 2015.

\section{PU Bambi}

2015 Sunčica - foto. - PU Bambi Kula <http://www.pubambi-kula. com/?page_id=21036>, accessed May 26, 2015. 


\section{Regionalna Radio televizija Vranje}

2015 Sveti prorok Jeremija slava vranjske policije. - Regionalna Radio televizija Vranje <http://www.rtv-vranje.rs/index.php?option=com_ k2\&view=item\&id=9964:sveti-prorok-jeremija-slava-vranjskepolicije\&Itemid=239>, accessed May 15, 2015.

\section{Skrozza, Tamara}

2002 Na konju u pantalonama. - Vreme $<$ http://www.vreme.com/cms/view. php?id=329587>, accessed May 18, 2015.

\section{Telegraf}

2015 Srećna ti slava Beograde: Evo kako je Spasovdan postao krsna slava naše prestonice! - Telegraf <http://www.telegraf.rs/vesti/ beograd/1576606-srecna-ti-slava-beograde-evo-kako-je-spasovdan-postao-krsna-slava-nase-prestonice >, accessed May 21, 2015.

2015 Slavimo Spasovdan: Beogradjani sa Patrijarhom i gradonačelnikom u svelanoj litiji (Foto). - Telegraf <http://www.telegraf.rs/vesti/ beograd/1576890-slavimo-spasovdan-beogradjani-sa-patrijarhom-i-gradonacelnikom-u-svecanoj-litiji-foto $>$, accessed May 21, 2015.

\section{TV Telemark}

2015 Društvo: Danas je Spasovdan - slava grada Čačka. - TV Telemark <http://tvtelemark.rs/?q=node/2431>, accessed May 21, 2015.

\section{Udruženje Srba Nemanja}

2009 Zašto Srbi slave krsnu slavu? <http://www.nemanja.de/trenutak-zadusu/194-zasto-srbi-slave-krsnu-slavu>, accessed May 5, 2015.

\section{Univerzitet u Beogradu, Pravni fakultet}

2013 Obeleženi Dan i slava Pravnog fakulteta. - Univerzitet u Beogradu, Pravni fakultet $<$ http://www.ius.bg.ac.rs/vesti2012-13.htm>, accessed May 25, 2015.

\section{Univerzitet u Nišu, Ekonomski fakultet}

2015 Sveti Sava: Slava fakulteta. - Univerzitet u Nišu, Ekonomski fakultet $<$ http://www.eknfak.ni.ac.rs/gallery.php?lang=srl\&album_id=18>, accessed May 22, 2015.

\section{Večernje novosti online}

2015 Litija centralnim gradskim ulicama povodom Spasovdana. - Večernje novosti online <http://www.novosti.rs/vesti/beograd.74.html:549187Litija-centralnim-gradskim-ulicama-povodom-Spasovdana>, accessed 21 May, 2015. 
